\title{
Effect of fruit ripening on bioactive compounds and antioxidant capacity of apple beverages
}

\author{
Karolline Marques da SILVA ${ }^{1}$, Acácio Antonio Ferreira ZIELINSKI ${ }^{2}$, Laís BENVENUTTI ${ }^{1}$, \\ Débora Gonçalves BORTOLINI ${ }^{1}$, Danianni Marinho ZARDO ${ }^{1}$, Flávio Luís BELTRAME ${ }^{1}$, \\ Alessandro NOGUEIRA ${ }^{1}$, Aline ALBERTI ${ }^{1 *}$
}

\begin{abstract}
The effect of the variety (Gala, Lis Gala and Fuji Suprema) and the ripening stage (unripe, ripe and senescent) of apples on the phenolic compounds (HPLC) and antioxidant capacity (FRAP and DPPH) of apple juices and ciders were evaluated. The phenolic content of the Gala and Lis Gala apple juices decreased from the unripe to ripe stages and increased from the ripe to the senescent stages, while in the case of Fuji Suprema these values decreased with senescence. Fermentation caused a reduction (17 to 50\%) of phenolics and the most affected were hydroxycinnamic acids and flavanols. Principal component analysis confirmed the influence of variety, and the use of multivariate regression (PLS) made it possible to create significant models $(\mathrm{p}<0.05)$ to predict the antioxidant activity. The phenolic composition of the juices at different ripening stages was related to the variety of apple, which influenced the effect of fermentation on these compounds.
\end{abstract}

Keywords: phenolic classes; HPLC; PCA; multivariate regression PLS; FRAP; DPPH.

Practical Application: Beverage production has been improved to meet the requirement of consumers in terms of bioactive compounds and nutrients. In this way, the knowledge about the influence of apple variety and its ripening stage in these parameters can contribute to increasing the antioxidant capacity and the quality of the apple beverages.

\section{Introduction}

Apples (Malus domestica Borkh) has high phenolic compounds content (Khanizadeh et al., 2008; Goulas et al., 2014). In apple juice and cider, phenolics can contribute to the sensory characteristics, such as their color, astringent and bitter taste. Moreover, phenolic compounds have demonstrated potent antioxidant properties in various systems that exhibit biological activity due to their cytoprotective properties (Babbar et al., 2015; Yassin et al., 2017). These compounds are related with reduction of the risk of incidence of various diseases such as cancer, coronary and neurodegenerative diseases (Alzheimer's and Parkinson's) (Hyson, 2011).

In the processing of apple juice or apple must to obtain fermented beverages (cider) there is significant loss of phenolic compounds. In the extraction of juice by the traditional method using pressing, about 42 to $58 \%$ of phenolic compounds are retained in the apple pomace (Van der Sluis et al., 2002). Among those phenolic compounds which are extracted to the juice, about 20 to $60 \%$ are oxidised by the polyphenol oxidase (Zardo et al., 2013). Thus, the processing of dessert apples results in a juice or cider with only 3 to $10 \%$ of the antioxidant activity of the intact fruit (Ćetković et al., 2008).

In several countries, fruits that are not considered to be commercially marketable, or fruits that do not have acceptable physical characteristics (appearance, size and shape) for fresh consumption, are used for processing into juice. Therefore, these fruits at different ripening stages are processed without prior classification. Information about the influence of the ripening stage on the concentration of phenols in dessert apples for beverage processing is essential in order to obtain a product with high levels of sensory and functional characteristics. Consequently, the aim of this study was to evaluate the influence of the cultivar and the ripening stage of the raw material on the phenolic content and antioxidant activity of apple juices and ciders.

\section{Materials and methods}

\subsection{Samples}

Samples of the Fuji Suprema and Lis Gala apple varieties were harvested at the Experimental Station of the Agricultural and Rural Extension (EPAGRI) in Santa Catarina, Brazil ( $\left.26^{\circ} 46^{\prime} 31^{\prime \prime} \mathrm{S}, 51^{\circ} 00^{\prime} 54^{\prime \prime} \mathrm{O}\right)$. The Gala variety was harvested from Boutin Agricola Company in Paraná, Brazil (25 32' 08” S, $49^{\circ} 53^{\prime} 33^{\prime \prime} \mathrm{O}$ ). The varieties were chosen based on world apple production. Gala, Fuji and their clones are among the five most produced varieties in the world. The fruits were harvested $(20 \mathrm{~kg})$ at three ripening stages (unripe, ripe and senescent) from different cardinal points, and from the top and the bottom of six trees. The maturation index was determined by using the Starch-iodine test according Blanpied \& Silsby (1992) using an

${ }^{1}$ Programa de Pós-graduação em Ciência e Tecnologia de Alimentos, Universidade Estadual de Ponta Grossa - UEPG, Ponta Grossa, PR, Brasil

${ }^{2}$ Departamento de Engenharia Química e Engenharia de Alimentos, Universidade Federal de Santa Catarina - UFSC, Florianópolis, SC, Brasil

*Corresponding author: alinealberti@gmail.com 
eight point scale. The unripe fruits used in the experiments had an index of 1 , while the ripe and senescent apples had indices of 4 - 5 and 8 , respectively.

\subsection{Methods}

Apple juice and cider processing

Samples of apples were selected, sanitised (Gomes et al., 2014) and crushed in a microprocessor (Metvisa, Type MPA, Brazil). The grated mass was placed in plastic screens (polyethylene thread $0.27 \mathrm{~mm}$ ) and subjected to a pressure of $294 \mathrm{kPa}$ for $5 \mathrm{~min}$ (Eureka Hydraulic press, Brazil). The juice was depectinised

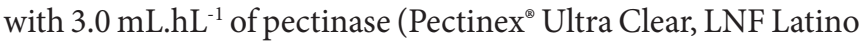
Americana, Novozymes, Brazil) at $40{ }^{\circ} \mathrm{C}$ for $60 \mathrm{~min}$ and after sedimentation it was racked. Part of the despectinised apple juice was bottled and frozen $\left(-18^{\circ} \mathrm{C}\right)$ until further analysis (Figure 1 ).
The other part of the despectinised apple juices was fermented with the yeast Saccharomyces cerevisiae r.f. cerevisiae (inoculated at $2.10^{6}$ cells. $\mathrm{mL}^{-1}$; Fermol Bouquet, AEB Group, Italy) under anaerobiosis to obtain the ciders. Alcoholic fermentation was conducted at $20-23^{\circ} \mathrm{C}$ until complete utilization of fermentable sugars $\left(<0.1\right.$ g. $\left.\mathrm{L}^{-1}\right)$. The ciders were then centrifuged $(8000 \mathrm{~g}$ at $4{ }^{\circ} \mathrm{C}$ for 20 minutes) (HIMAC CR-GII, Hitachi, Japan) and bottled. The cider samples were kept at $-18{ }^{\circ} \mathrm{C}$ until further analysis. All process (juice and cider) was made in duplicate.

Total phenolic compounds, total flavonoids and total flavanols

The analysis of phenolic compounds was performed by the Folin-Ciocalteu method (Singleton \& Rossi, 1965). Results were expressed as milligrams of 5-caffeoylquinic acid equivalents per litre of apple juice or cider using a calibration curve. The total flavonoid content (TFC) of the juices and ciders was performed according to method described by Zhishen et al. (1999). The results

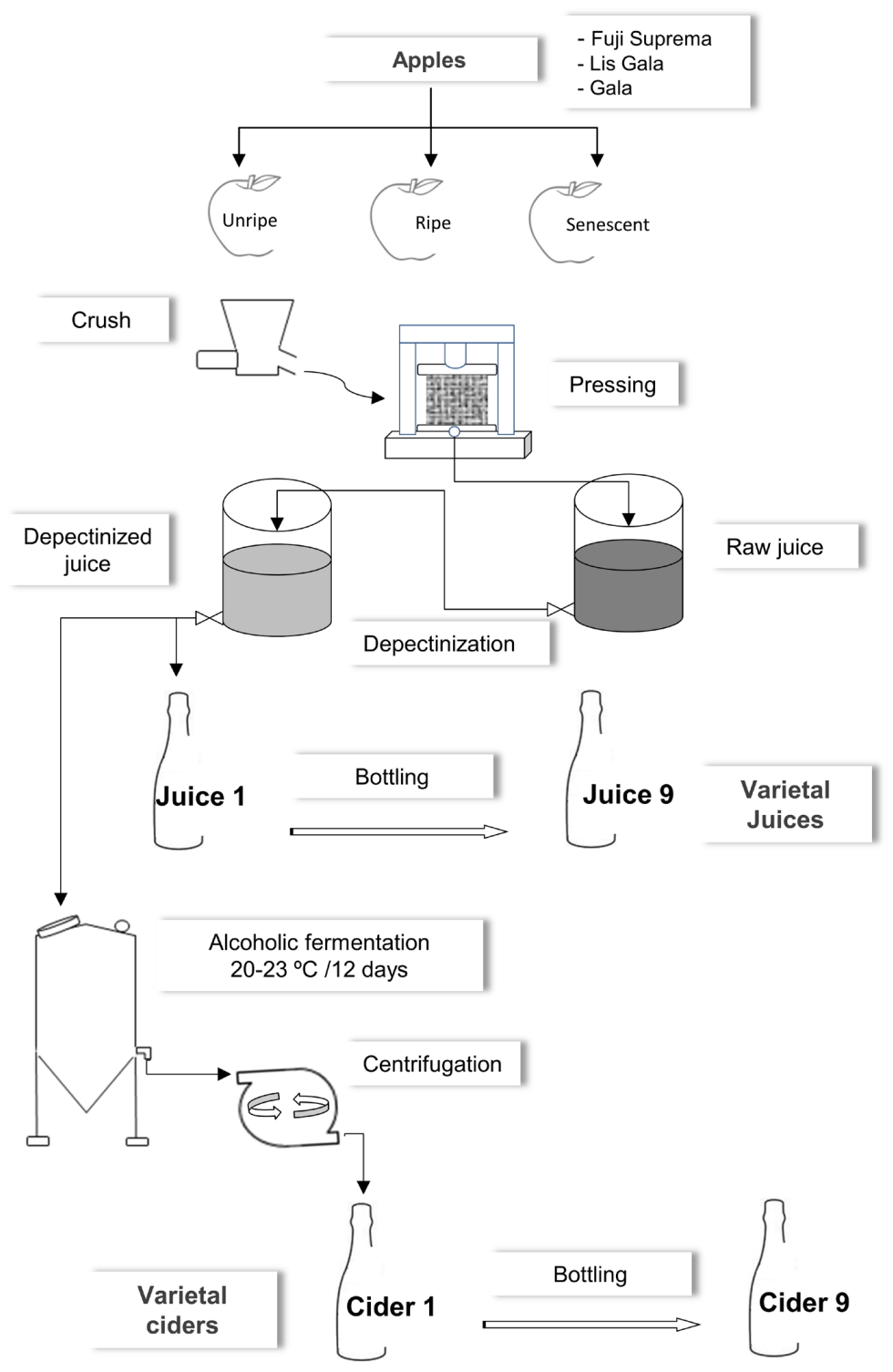

Figure 1. Scheme of apple juices and ciders processing with fruit at different ripening stages. 
were expressed as milligrams of catechin equivalents (CTE) using a calibration curve. The vanillin- $\mathrm{HCl}$ method was used for the determination of flavanols (Broadhurst \& Jones, 1978); results were expressed in catechin equivalents.

\section{Antioxidant capacity}

The antioxidant capacity was evaluated in the apple juices and ciders using the FRAP (Benzie \& Strain, 1996) and DPPH (Brand-Williams et al., 1995) methods. To estimate the antioxidant capacity, the variation in absorbance between the FRAP reagent and the mixture (FRAP reagent and sample) was correlated with a calibration curve of Trolox $\left(0.1\right.$ to $\left.1.0 \mathrm{mmol} . \mathrm{L}^{-1}\right)$. The results were expressed in Trolox equivalents per litre of apple juice or cider $\left(\mu \mathrm{mol} \mathrm{TE} . \mathrm{L}^{-1}\right)$. The assay is based on the reducing power of antioxidants present in extracts, in which a potential antioxidant reduces the ferric ion $\left(\mathrm{Fe}^{3+}\right)$ to ferrous ion $\left(\mathrm{Fe}^{2+}\right)$; the latter forms a blue complex $\left(\mathrm{Fe}^{2+} / \mathrm{TPTZ}\right)$.

The antiradical capacity determined by the DPPH method was defined as the amount of apple necessary to decrease the $\mathrm{DPPH}$ concentration by $50 \%$ or the $\mathrm{EC}_{50}$; the lower the $\mathrm{EC}_{50}$, the higher the antioxidant power. This method determines the hydrogen donating capacity of molecules and does not produce oxidative chain reactions or react with free radical intermediates.

\section{HPLC analysis of phenolic compounds}

Samples $(8 \mathrm{~mL})$ of each apple juice and cider were lyophilized (LS 3000 Terroni, BR) and reconstituted with a solution $(4 \mathrm{~mL})$ of $2.5 \%$ acetic acid and methanol $(3: 1, \mathrm{v} / \mathrm{v})$ for the analysis of the individual phenolic compounds and their classes.

The chromatographic analysis was performed according to Alberti et al. (2014) in a chromatographic system, Waters 2695 Alliance (USA), which was equipped with a Symmetry $\mathrm{C}_{18}(4.6 \times 150 \mathrm{~mm}, 3.5 \mu \mathrm{m})$ column (Waters, USA) and a photodiode array detector PDA 2998 (Waters, USA). The identification and quantification of the compounds was performed by comparison of the retention times and spectra of the calibration curve of standards. For the compounds where commercial standards were not available, the quantification was performed from compounds belonging to the same class of phenolic compounds, as verified by fractionation (Picinelli-Lobo et al., 2009).

The fractionation was performed according to the method proposed by Oszmianski et al. (1988). The total peak area, which was obtained by HPLC analysis, was summed for each phenolic class and quantified as 5-caffeoylquinic acid, quercetin 3-glucoside and phloridzin equivalents for phenolic acids, flavonols and dihydrochalcones, respectively.

\section{Statistical analysis}

The data were presented as mean and standard deviation (SD). The Shapiro-Wilk and Hartley tests were used to check for normality of distribution and homogeneity of variances, respectively. Differences between samples were assessed by one-way ANOVA, followed by Fisher's LSD test. Pearson products (r) were used to evaluate the strength of correlation among the parameters that were evaluated. A p-value below 0.05 was considered to be significant.

Principal component analysis (PCA) was applied to separate the samples according to their values of responses. Before applying PCA, all the variables were auto scaled to standardize their statistical significance.

Multivariate regression by partial least squares (PLS) was used to predict the antioxidant activity of the juices and ciders. The antioxidant activity was used as the dependent variable (Yi), and the total phenolic compounds, phenolic acids, flavonoids, flavanols, flavonols and dihydrochalcones were used as the independent variables $\left(\mathrm{X}_{\mathrm{n}}\right)$. Linear models were constructed, as can be observed in Equation 1.

$$
Y=\beta_{0}+\sum_{i=1}^{n} \beta_{i} X_{i}
$$

where $Y$ is the predicted response and $\beta_{0}$, and $\beta$, are the regression coefficients. Initially, all the variables were autoescaled and the models were established.

The statistical significance of the equations was examined by ANOVA and the adequacy and quality of the models were evaluated by regression coefficients $\left(\mathrm{R}^{2}\right)$, adjusted $\mathrm{R}^{2}$ and calculation of the root mean square error of calibration (RMSEC) (Zielinski et al., 2014b). The statistical analysis was performed using Statistica 7.0 software (StatSoft Inc., USA).

\section{Results and discussion}

\subsection{Influence of ripening stage on phenolic compounds of the juices}

A significant variation $(\mathrm{p}<0.05)$ in the total phenolic compound content was observed between varietal apple juices (326 to $583 \mathrm{mg} . \mathrm{L}^{-1}$ ) at different ripening stages (Table 1), as previously reported in other studies (Valavanidis et al., 2009; Zardo et al., 2013; Le Bourvellec et al., 2015). These values are typical of apple juices that were processed with dessert apples and obtained by the traditional method by pressing, without antioxidants (Guo et al., 2013).

No significant difference was observed $(\mathrm{p}>0.05)$ between the total phenolic content of the juices at different ripening stages for the Fuji Suprema and Lis Gala varieties. However, in the Gala apple juice (highest phenolic compounds content) showed a decrease from the unripe to ripe stages, followed by an increase until the senescent stage. This could also be observed in the analysis of the phenolic classes, except for the dihydrochalcones. Alberti et al. (2017) also found reduction of dihydrochalcones with senescence in fruits of Gala variety.

Flavonoids were the main phenolic compounds class quantified in the apple juices (32\%) and within this class, flavanols represented $70 \%$ of the total, followed by dihydrochalcones (15\%) and flavonols (11\%). In the Gala and Lis Gala varieties, the flavonoid and flavonol contents evolved in the same manner as the total phenols in the Gala variety; in other words, there was a decrease in flavonoid content from the unripe to the ripe stage, followed by an increase until the senescent stage. The increase 
Silva et al.

Table 1. Phenolic compounds (mg. $\left.\mathrm{L}^{-1}\right)$ and antioxidant capacity of juices $(\mathrm{n}=18)$ and ciders $(\mathrm{n}=18)$ made from unripe ripe and senescent apples.

\begin{tabular}{|c|c|c|c|c|c|c|c|c|c|}
\hline \multirow[b]{2}{*}{ Variety } & \multirow[b]{2}{*}{$\begin{array}{l}\text { Ripening } \\
\text { stage }\end{array}$} & \multirow{2}{*}{$\begin{array}{c}\text { Total } \\
\text { phenolic } \\
\text { compounds }\end{array}$} & \multirow{2}{*}{$\begin{array}{l}\text { Hydroxycinnamic } \\
\text { Acids }\end{array}$} & \multirow[b]{2}{*}{ Flavonoids } & \multirow[b]{2}{*}{ Flavanols } & \multirow[b]{2}{*}{ Flavonols } & \multirow[b]{2}{*}{ Dihydrochalcones } & \multicolumn{2}{|c|}{ Antioxidant capacity } \\
\hline & & & & & & & & $\begin{array}{c}\text { FRAP }^{*} \\
\left(\mu \text { molTE. }^{-1}\right)\end{array}$ & $\begin{array}{l}\mathrm{DPPH}^{* *} \\
\left(\mathrm{mg} \cdot \mathrm{L}^{-1}\right)\end{array}$ \\
\hline \multicolumn{10}{|c|}{ Juices } \\
\hline \multirow{2}{*}{$\frac{\pi}{\tilde{J}}$} & ripe & $509 \pm 9^{c}$ & $79 \pm 1^{g}$ & $157 \pm 4^{\mathrm{e}}$ & $125.4 \pm 0.6^{\mathrm{d}}$ & $11.3 \pm 0.2^{\mathrm{i}}$ & $18.69 \pm 0.04^{\mathrm{fg}}$ & $637 \pm 12^{\mathrm{e}}$ & $409 \pm 1 . j$ \\
\hline & senescent & $551 \pm 11^{\mathrm{b}}$ & $125 \pm 2^{c}$ & $192 \pm 6^{a}$ & $150.2 \pm 0.6^{\mathrm{a}}$ & $13.7 \pm 0.2^{\text {bcde }}$ & $18.23 \pm 0.04^{\mathrm{fgh}}$ & $908 \pm 24^{\mathrm{a}}$ & $361.5 \pm 0.5^{\mathrm{m}}$ \\
\hline \multirow{2}{*}{ 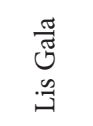 } & unripe & $408 \pm 8^{\mathrm{de}}$ & $115.2 \pm 0.3^{\mathrm{d}}$ & $166 \pm 6^{\mathrm{d}}$ & $121 \pm 2^{\mathrm{e}}$ & $11.4 \pm 0.6^{\mathrm{i}}$ & $18.80 \pm 0.03^{\mathrm{fg}}$ & $725 \pm 34^{\mathrm{d}}$ & $656 \pm 1^{\mathrm{d}}$ \\
\hline & senescent & $393 \pm 8^{\text {ef }}$ & $96 \pm 2^{\mathrm{f}}$ & $163 \pm 5^{\mathrm{de}}$ & $129 \pm 1^{c}$ & $13.1 \pm 0.8^{\mathrm{efg}}$ & $15.70 \pm 0.09^{\mathrm{kl}}$ & $695 \pm 45^{\mathrm{d}}$ & $415.5 \pm 0.5^{\mathrm{i}}$ \\
\hline \multirow{3}{*}{ :尝泀 } & unripe & $326 \pm 6^{g}$ & $79 \pm 1^{g}$ & $102 \pm 4^{\mathrm{i}}$ & $59 \pm 2^{j}$ & $12.6 \pm 0.5^{\mathrm{gh}}$ & $26.41 \pm 0.09^{\mathrm{a}}$ & $601 \pm 29^{\mathrm{ef}}$ & $654.5 \pm 0.7^{\mathrm{d}}$ \\
\hline & ripe & $343 \pm 6^{g}$ & $47 \pm 1^{j}$ & $76 \pm 6^{\mathrm{k}}$ & $41 \pm 1^{\mathrm{k}}$ & $12.4 \pm 0.4^{\mathrm{gh}}$ & $18.1 \pm 0.1^{\mathrm{gh}}$ & $527 \pm 25^{g}$ & $825 \pm 2^{\mathrm{a}}$ \\
\hline & senescent & $341 \pm 4^{g}$ & $40 \pm 1^{\mathrm{k}}$ & $73 \pm 4^{\mathrm{k}}$ & $29 \pm 1^{1}$ & $12.9 \pm 0.4^{\mathrm{fgh}}$ & $15.5 \pm 0.1^{1}$ & $358 \pm 29^{\mathrm{h}}$ & $822 \pm 2^{\mathrm{a}}$ \\
\hline \multicolumn{10}{|c|}{ Ciders } \\
\hline \multirow{3}{*}{$\begin{array}{l}\frac{\pi}{\pi} \\
\tilde{U} \\
.]\end{array}$} & unripe & $336 \pm 6^{g}$ & $115 \pm 3^{\mathrm{d}}$ & $183 \pm 1^{\mathrm{bc}}$ & $113.3 \pm 0.9^{f}$ & $16.4 \pm 0.5^{\mathrm{a}}$ & $23.4 \pm 0.5^{c}$ & $639 \pm 20^{\mathrm{e}}$ & $367 \pm 3^{1}$ \\
\hline & ripe & $287 \pm 8^{\mathrm{h}}$ & $105 \pm 2^{\mathrm{e}}$ & $147 \pm 1^{\mathrm{f}}$ & $87 \pm 2^{\mathrm{h}}$ & $13.6 \pm 0.9^{\text {cdef }}$ & $20.6 \pm 0.5^{\mathrm{d}}$ & $582 \pm 17^{f}$ & $521 \pm 5^{\mathrm{f}}$ \\
\hline & senescent & $326 \pm 8^{g}$ & $131 \pm 2^{\mathrm{b}}$ & $179 \pm 2^{c}$ & $133 \pm 3^{\mathrm{b}}$ & $13.9 \pm 0.4^{\mathrm{bcd}}$ & $24.7 \pm 0.2^{\mathrm{b}}$ & $781 \pm 19^{c}$ & $398 \pm 6^{\mathrm{k}}$ \\
\hline \multirow{3}{*}{ 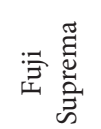 } & unripe & $210 \pm 8^{i}$ & $63.7 \pm 0.8^{\mathrm{h}}$ & $88 \pm 2^{\mathrm{j}}$ & $25 \pm 1^{\mathrm{m}}$ & $12.6 \pm 0.4^{\mathrm{gh}}$ & $13.60 \pm 0.09^{\mathrm{m}}$ & $403 \pm 37^{\mathrm{h}}$ & $740 \pm 1^{c}$ \\
\hline & ripe & $199 \pm 15^{\mathrm{i}}$ & $55 \pm 2^{\mathrm{i}}$ & $90 \pm 3^{j}$ & $26.3 \pm 0.5^{\mathrm{lm}}$ & $12.1 \pm 0.3^{\mathrm{hi}}$ & $19.07 \pm 0.03^{\mathrm{ef}}$ & $398 \pm 12^{\mathrm{h}}$ & $740.0 \pm 0.6^{c}$ \\
\hline & senescent & $201 \pm 10^{\mathrm{i}}$ & $40 \pm 2^{\mathrm{k}}$ & $63 \pm 2^{1}$ & $12.1 \pm 0.9^{\mathrm{n}}$ & $10.3 \pm 0.7^{j}$ & $15.0 \pm 0.1^{1}$ & $370 \pm 28^{\mathrm{h}}$ & $747 \pm 1^{\mathrm{b}}$ \\
\hline
\end{tabular}

${ }^{*}$ Ferric reducing antioxidant power (FRAP); ${ }^{* *}$ Antioxidant activity by DPPH (2,2-diphenyl-2-picrylhydrazyl) method. Different letters in the same column represent statistical different results according to the Fischer LSD test $(p \leq 0.05)$.

observed between the ripe and senescent stages may have been related to higher activity of the pectinolytic enzymes of the fruits (Goulão et al., 2007), which facilitates the extraction during juice processing (Zielinski et al., 2014a) and not due to a synthesis process.

The monomeric flavonoid identified in the largest quantities in the apple juice was phloridzin (from $8.7 \mathrm{mg} . \mathrm{L}^{-1}$ in Senescent Lis Gala to $19.5 \mathrm{mg.L} \mathrm{L}^{-1}$ in unripe Fuji Suprema juice). Apples, and a few other species of the Rosaceae and Ericaceae families, have phloridzin in their composition, however, only apples contain high levels of this compound (Gosch et al., 2010; Turner et al., 2005). The highest concentrations of phloridzin were observed in unripe juices, with $13.6 ; 10.3$ and $19.5 \mathrm{mg} . \mathrm{L}^{-1}$ in samples of the Gala, Lis Gala and Fuji Suprema varieties, respectively, which decreased about $30 \%$ with senescence. Despite the reduction in the phloridzin content with fruit ripening, dihydrochalcones levels remained stable in juices from the Gala and Lis Gala varieties.

Hydroxycinnamic acids are the second largest class of phenolic compounds found in apples and within this group 5-caffeoylquinic acid is the compound with the highest concentration in juices and ciders (Goulas et al., 2014; Khanizadeh et al., 2008). The highest levels of 5-caffeoylquinic acid were found in the juices from unripe apples, and a reduction with ripening was observed in all cultivars. The content ranged from 85.69 to $52.18 \mathrm{mg} . \mathrm{L}^{-1}$ in Gala apple juice and from 40.8 to $25.3 \mathrm{mg} \cdot \mathrm{L}^{-1}$ in Fuji Suprema, a variation of about $40 \%$, while in Lis Gala this variation was $15 \%$ (66.1 to $\left.56.1 \mathrm{mg} \cdot \mathrm{L}^{-1}\right)$.
The Gala juices from unripe and senescent apples had the highest levels for antioxidant activities by the FRAP method; while in the Fuji Suprema juices the highest values were found in the unripe stage, and these decreased with maturation. The samples of Lis Gala juices showed no significant difference in terms of antioxidant activity (FRAP) between the samples that were analysed. The results of antioxidant activity obtained by the FRAP method were correlated to those found by DPPH $(\mathrm{r}=-0.82, \mathrm{p}<0.001)$.

The flavonoid content was highly correlated with the antioxidant activity of the samples (FRAP, $\mathrm{r}=0.92, \mathrm{p}<0.001$; $\mathrm{DPPH}, \mathrm{r}=-0.88, \mathrm{p}<0.01$ ) and in this class the flavanols had the highest significant correlation (FRAP, $\mathrm{r}=0.91, \mathrm{p}<0.01$; $\mathrm{DPPH} r=-0.91, \mathrm{p}<0.01)$. Polymers of catechin and epicatechin (procyanidins) are the major flavanols found in apples and they are recognised for high antioxidant activity and health benefits (Guyot et al., 2002).

The phenolic acids were also significantly correlated with antioxidant activity (FRAP, $\mathrm{r}=0.94, \mathrm{p}<0.001 ; \mathrm{DPPH}, \mathrm{r}=-0.74$, $\mathrm{p}=0.02$ ). Among the identified phenolic monomers, 5 -caffeoylquinic acid showed a significant correlation (FRAP, $\mathrm{r}=0.96, \mathrm{p}<0.001$; DPPH, $\mathrm{r}=-0.82, \mathrm{p}<0.01$ ), unlike phloridzin (FRAP, $\mathrm{r}=-0.22$, $\mathrm{p}=0.57 ; \mathrm{DPPH}, \mathrm{r}=0.39, \mathrm{p}=0.29)$. Tsao et al. (2005) and Picinelli-Lobo et al. (2009) have demonstrated that phloridzin has a very low activity with FRAP and DPPH reagent. However, this compound is related to the reduction of risks of the incidence of some diseases such as diabetes and other neurological diseases, 
as well as being used in research as an additive in foods and beverages (Gosch et al., 2010; Guyot et al., 2007).

\subsection{Influence of fermentation and ripening stage on phenolics of the ciders}

The phenolic composition was changed during the fermentation (Table 1). The reduction in total phenols ranged from $17 \%$ (senescent Lis Gala) to $50 \%$ (unripe Gala). The Gala variety had the highest content of total phenols, however, the greatest reduction was also observed in this cultivar, resulting in ciders with levels similar to the Lis Gala variety.

The average of total phenols indicated that the transformation of the juices ( $426 \mathrm{mg} \cdot \mathrm{L}^{-1}$ ) to ciders ( $289 \mathrm{mg} . \mathrm{L}^{-1}$ ) was responsible for a $32 \%$ reduction in phenolic compounds. However, the reduction of the phenolic classes was lower (14\%), which was consistent with a reduction in antioxidant activity as measured by FRAP (10\%). The greater reduction observed by the analysis of total phenols may have been related to interfering compounds in the juice, such as sugar and amino acids, which can react with the Folin Ciocalteu reagent (Everette et al., 2010; Prior et al., 2005). Apple juice has sugars (fructose, glucose and sucrose) and amino acids that are consumed during fermentation by the yeast (Santos et al., 2016).

The most affected classes were the phenolic acids in the Gala variety and the flavanols in Fuji Suprema. According to Caridi et al. (2004), the effect of yeast can change the phenolic profile of wines and this can be explained by its ability to adsorb phenols (Márquez et al., 2009); the cell wall polarity of the yeast defines the ability of the yeast to adsorb various molecules such as volatile compounds, fatty acids, and pigments. In addition, the yeast Saccharomyces cerevisiae is capable of converting the phenolic acids of the apple must to vinyl phenols by decarboxylation. The activity of the enzyme cinnamate carboxy-lyase (SCD) only occurs during alcoholic fermentation and the intensity depends on the strain that is used (Chatonnet et al., 1993).

The antioxidant activity did not change uniformly due to changes in the phenolic compounds. The correlation with flavonoids remained high (FRAP, $r=0.90, p=0.01$; DPPH, $\mathrm{r}=-0.98, \mathrm{p}<0.001$ ) because the fraction of these compounds, which represented $32 \%$ of total phenols of the juices, increased to $45 \%$ in the ciders. The flavanols showed a higher correlation with the antioxidant activity of the ciders (FRAP, $\mathrm{r}=0.96, \mathrm{p}<0.001$; $\mathrm{DPPH}, \mathrm{r}=-0.97, \mathrm{p}<0.001)$. The change in the content of phenolic acids due to fermentation caused a decrease in the correlation with antioxidant activity measured by FRAP $(r=0.69, p=0.04)$, while that obtained by the DPPH method increased $(r=-0.85$, $\mathrm{p}=0.004)$. The same behaviour was observed for 5 -caffeoylquinic acid (FRAP, $r=0.80, p=0.01$; DPPH $r=-0.86, p=0.003$ ), which was the major representative of the hydroxycinnamic acids.

\subsection{Multivariate analysis of data}

Principal component analysis (PCA) was performed to evaluate the data related to the phenolic composition and the antioxidant capacity of the juices and ciders obtained from fruits at different ripening stages.

The scatter plot (Figure 2) suggested the formation of three groups. The group on the right side of the scatter plot was formed by the beverages produced with Fuji Suprema apples that had

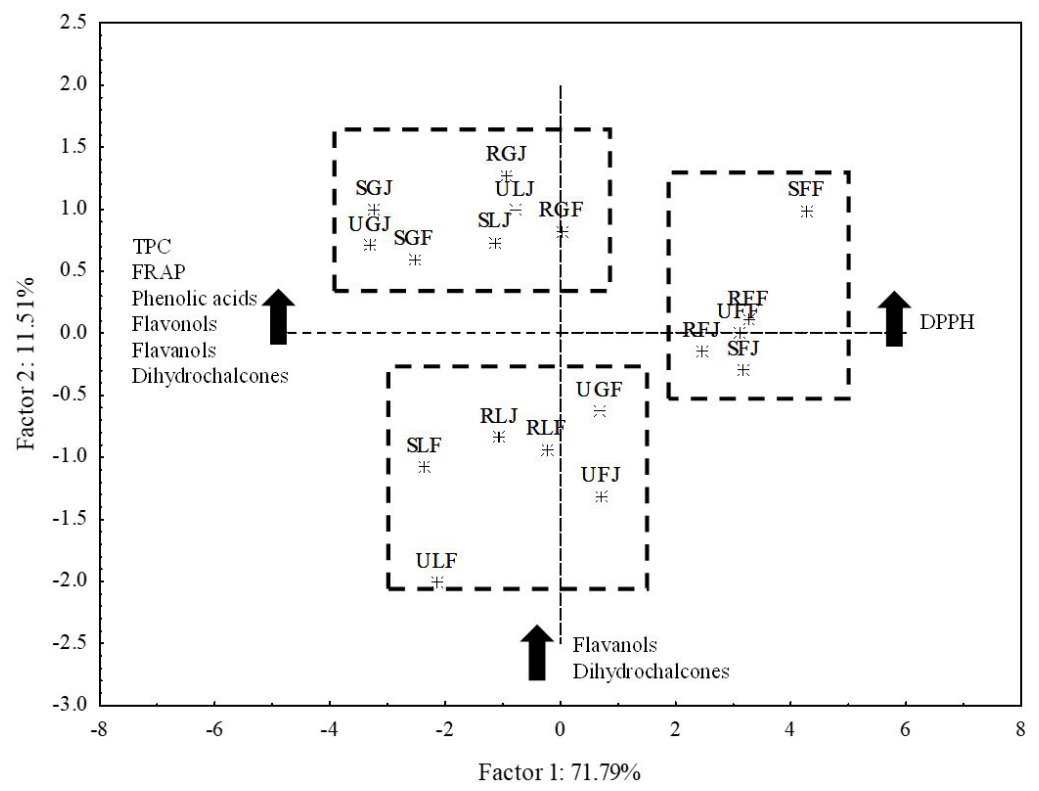

Figure 2. A scatter plot (PC1 vs. PC2) on the main phenolic classes and antioxidant capacity among the apple beverages produced in different ripening stages. Abbreviations: UGJ = Unripe Gala juice; RGJ = Ripe Gala juice; SGJ = Senescent Gala juice; ULJ = Unripe Lis Gala juice; RLJ = Ripe Lis Gala juice; SLJ = Senescent Lis Gala juice; UFJ = Unripe Fuji Suprema juice; RFJ = Ripe Fuji Suprema juice; SFJ = Senescent Fuji Suprema juice; UGF = Unripe Gala cider; RGF = Ripe Gala cider; SGF = Senescent Gala cider; ULF = Unripe Lis Gala cider; RLF = Ripe Lis Gala cider; SLF = Senescent Lis Gala cider; UFF = Unripe Fuji Suprema cider; RFF = Ripe Fuji Suprema cider; SFF = Senescent Fuji Suprema cider; TPC $=$ Total phenolic compounds; FRAP = ferric reducing antioxidant power (FRAP); DPPH = antioxidant activity by DPPH (2,2-diphenyl-2-picrylhydrazyl) method. 
high DPPH values (lower antioxidant capacity). The two other groups were formed by the beverages produced from the Gala and Lis Gala cultivars, which had higher levels of phenolic compounds and antioxidant capacity. The sample of unripe Fuji Suprema juice in the Gala and Lis Gala group showed the influence of the ripening stage on the content of phenolic compounds in apples.

In order to predict the antioxidant capacity using the FRAP and DPPH methods in a quick and easy manner, linear models were built for the apple beverages using multivariate PLS regression as a function of total phenols and classes analysed by HPLC. Multiple regression analysis of FRAP values showed that the model (Equation 2) was significant $(\mathrm{p}<0.0001)$ and could explain $84.15 \%\left(\mathrm{R}^{2} \mathrm{adj}=83.10 \%\right)$ of all variance in the data. The RMSEC value for the model was $90.81 \mu \mathrm{mol} . \mathrm{L}^{-1}$ (11.22\% error).

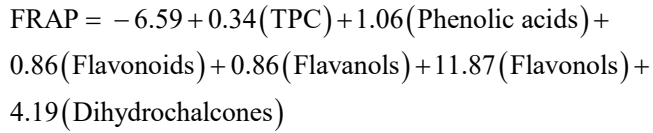

The model for the DPPH assay (Equation 3) was also significant $(\mathrm{p}<0.0001)$ and could explain $79.72 \%\left(\mathrm{R}^{2} \mathrm{adj}=78.45 \%\right)$ of the total variance. The RMSEC of the model was $77.66 \mathrm{mg} \cdot \mathrm{L}^{-1}$ (14.00\% error).

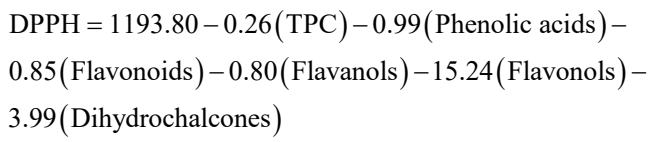

Although it was only used a limited number of samples, PLS appears to be a suitable approach to predict the antioxidant capacity of apple beverages.

\section{Conclusion}

The phenolic content in apple juices at different ripening stages is related to variety. The contents of the main constituents of the Gala and Lis Gala apple juices decreased from the unripe to ripe stages and increased from the ripe to senescent stages, while in the Fuji Suprema variety these values decreased with senescence. The fermentation of the juice for cider production reduced the phenolic content and mainly affected the phenolic acids and flavanols ( $>$ ripening stage $<$ phenolic losses).

\section{Acknowledgements}

The authors are deeply grateful to National Counsel of Technological and Scientific Development (310425/2013-1, CNPq), Araucaria Foundation (227/2014, FA) and Coordination for the Improvement of Personnel in Higher Level (A. A. F. Zielinski, PNPD/CAPES) for the financial support and scholarships offered during the period of this research and also to LNF Latino Americana of Bento Gonçalves (RS) for the donation of enzymes.

\section{References}

Alberti, A., Zielinski, A. A. F., Couto, M., Judacewski, P., Mafra, L. I., \& Nogueira, A. (2017). Distribution of phenolic compounds and antioxidant capacity in apples tissues during ripening. Journal of Food Science and Technology, 54(6), 1511-1518. http://dx.doi. org/10.1007/s13197-017-2582-z. PMid:28559610.

Alberti, A., Zielinski, A. A. F., Zardo, D. M., Demiate, I. M., Nogueira, A., \& Mafra, L. I. (2014). Optimisation of the extraction of phenolic compounds from apples using response surface methodology. Food Chemistry, 149, 151-158. http://dx.doi.org/10.1016/j. foodchem.2013.10.086. PMid:24295689.

Babbar, N., Oberoi, H. S., \& Sandhu, S. K. (2015). Therapeutic and nutraceutical potential of bioactive compounds extracted from fruit residues. Critical Reviews in Food Science and Nutrition, 55(3), 319-337. http://dx.doi.org/10.1080/10408398.2011.653734. PMid:24915390.

Benzie, I. F., \& Strain, J. J. (1996). The ferric reducing ability of plasma (FRAP) as a measure of "antioxidant power": the FRAP assay. Analytical Biochemistry, 239(1), 70-76. http://dx.doi.org/10.1006/ abio.1996.0292. PMid:8660627.

Blanpied, G. D., \& Silsby, K. J. (1992). Predicting harvest date windows for apples (Bulletin, No. 221). Ithaca: Cornell Cooperative Extension Information.

Brand-Williams, W., Cuvelier, M. E., \& Berset, C. (1995). Use of a free radical method to evaluate antioxidant activity. LebensmittelWissenschaft + Technologie, 28(1), 25-30. http://dx.doi.org/10.1016/ S0023-6438(95)80008-5.

Broadhurst, R. B., \& Jones, W. T. (1978). Analysis of condensed tannins using acidified vanillin. Journal of the Science of Food and Agriculture, 29(9), 788-794. http://dx.doi.org/10.1002/jsfa.2740290908.

Caridi, A., Cufari, A., Lovino, R., Palumbo, R., \& Tedesco, I. (2004). Influence of yeast on polyphenol composition of wine. Food Technology and Biotechnology, 42, 37-40.

Ćetković, G., Canadanovic-Brunet, J., Djilas, S., Savatovic, S., Mandic, A., \& Tumbas, V. (2008). Assessment of polyphenolic content and in vitro antiradical characteristics of apple pomace. Food Chemistry, 109(2), 340-347. http://dx.doi.org/10.1016/j.foodchem.2007.12.046. PMid:26003356.

Chatonnet, P., Dubourdieu, D., Boidron, J.-N., \& Lavigne, V. (1993). Synthesis of volatile phenols by Saccharomyces cerevisiae in wines. Journal of the Science of Food and Agriculture, 62(2), 191-202. http:// dx.doi.org/10.1002/jsfa.2740620213.

Everette, J. D., Bryant, Q. M., Green, A. M., Abbey, Y. A., Wangila, G. W., \& Walker, R. B. (2010). Thorough study of reactivity of various compound classes toward the Folin-Ciocalteu reagent. Journal of Agricultural and Food Chemistry, 58(14), 8139-8144. http://dx.doi. org/10.1021/jf1005935. PMid:20583841.

Gomes, T. A., Salvador, M. R., Fo., Zielinski, A. A. F., Pietrowski, G. A. M., \& Nogueira, A. (2014). Microbial levels in apple must and their association with fruit selection, washing and sanitization. Journal of Food Safety, 34(2), 141-149. http://dx.doi.org/10.1111/jfs.12107.

Gosch, C., Halbwirth, H., \& Stich, K. (2010). Phloridzin: biosynthesis, distribution and physiological relevance in plants. Phytochemistry, 71(8-9), 838-843. http://dx.doi.org/10.1016/j.phytochem.2010.03.003. PMid:20356611.

Goulão, L. F., Santos, J., de Sousa, I., \& Oliveira, C. M. (2007). Patterns of enzymatic activity of cell wall-modifying enzymes during growth and ripening of apples. Postharvest Biology and Technology, 43(3), 307-318. http://dx.doi.org/10.1016/j.postharvbio.2006.10.002.

Goulas, V., Kourdoulas, P., Makris, F., Theodorou, M., Fellman, J. K., \& Manganaris, G. A. (2014). Comparative polyphenolic antioxidant profile and quality of traditional apple cultivars as affected by cold storage. International Journal of Food Science \& Technology, 49(9), 2037-2044. http://dx.doi.org/10.1111/ijfs.12507. 
Guo, J., Yue, T., Yuan, Y., \& Wang, Y. (2013). Chemometric classification of apple juices according to variety and geographical origin based on polyphenolic profiles. Journal of Agricultural and Food Chemistry, 61(28), 6949-6963. http://dx.doi.org/10.1021/jf4011774. PMid:23815505.

Guyot, S., Le Bourvellec, C., Marnet, N., \& Drilleau, J. F. (2002). Procyanidins are the most abundant polyphenols in dessert apples at maturity. Lebensmittel-Wissenschaft + Technologie, 35(3), 289-291. http://dx.doi.org/10.1006/fstl.2001.0843.

Guyot, S., Serrand, S., LeQuéré, J. M., Sanoner, P., \& Renard, C. M. G. C. (2007). Enzymatic synthesis and physicochemical characterisation of phloridzin oxidation products (POP), a new water-soluble yellow dye deriving from apple. Innovative Food Science \& Emerging Technologies, 8(3), 443-450. http://dx.doi.org/10.1016/j.ifset.2007.03.021.

Hyson, D. A. (2011). A Comprehensive review of apples and apple components and their relationship to human health. Advances in Nutrition, 2(5), 408-420. http://dx.doi.org/10.3945/an.111.000513. PMid:22332082.

Khanizadeh, S., Tsao, R., Rekika, D., Yang, R., Charles, M. T., \& Rupasinghe, H. P. V. (2008). Polyphenol composition and total antioxidant capacity of selected apple genotypes for processing. Journal of Food Composition and Analysis, 21(5), 396-401. http:// dx.doi.org/10.1016/j.jfca.2008.03.004.

Le Bourvellec, C., Bureau, S., Renard, C. M., Plenet, D., Gautier, H., Touloumet, L., Girard, T., \& Simon, S. (2015). Cultivar and year rather than agricultural practices affect primary and secondary metabolites in apple fruit. PLoS One, 10(11), 1-23. http://dx.doi. org/10.1371/journal.pone.0141916. PMid:26618711.

Márquez, T., Millán, C., \& Salmon, J.-M. (2009). Plasma membrane sterols are involved in yeast's ability to adsorb polyphenolic compounds resulting from wine model solution browning. Journal of Agricultural and Food Chemistry, 57(17), 8026-8032. http://dx.doi.org/10.1021/ jf901629u. PMid:19691282.

Oszmianski, J., Ramos, T., \& Bourzeix, M. (1988). Fractionation of phenolic compounds in red wine. American Journal of Enology and Viticulture, 39, 259-262.

Picinelli-Lobo, A., García, Y. D., Sánchez, J. M., Madrera, R. R., \& Valles, B. S. (2009). Phenolic and antioxidant composition of cider. Journal of Food Composition and Analysis, 22(7-8), 644-648. http://dx.doi. org/10.1016/j.jfca.2009.03.008.

Prior, R. L., Wu, X., \& Schaich, K. (2005). Standardized methods for the determination of antioxidant capacity and phenolics in foods and dietary supplements. Journal of Agricultural and Food Chemistry, 53(10), 4290-4302. http://dx.doi.org/10.1021/jf0502698. PMid:15884874.

Santos, C. M. E., Alberti, A., Pietrowski, G. A. M., Zielinski, A. A. F., Wosiacki, G., Nogueira, A., \& Jorge, R. M. M. (2016). Supplementation of amino acids in apple must for the standardization of volatile compounds in ciders. Journal of the Institute of Brewing, 122(2), 334-341. http://dx.doi.org/10.1002/jib.318.
Singleton, V., \& Rossi, J. A. (1965). Colorimetry of total phenolics with phosphomolybdic-phosphotungstic acid reagents. American Journal of Enology and Viticulture, 16, 144-158.

Tsao, R., Yang, R., Xie, S., Sockovie, E., \& Khanizadeh, S. (2005). Which polyphenolic compounds contribute to the total antioxidant activities of apple? Journal of Agricultural and Food Chemistry, 53(12), 49894995. http://dx.doi.org/10.1021/jf048289h. PMid:15941346.

Turner, A., Chen, S.-N., Joike, M. K., Pendland, S. L., Pauli, G. F., \& Farnsworth, N. R. (2005). Inhibition of uropathogenic Escherichia coli by cranberry juice: a new antiadherence assay. Journal of Agricultural and Food Chemistry, 53(23), 8940-8947. http://dx.doi.org/10.1021/ jf052035u. PMid:16277386.

Valavanidis, A., Vlachogianni, T., Psomas, A., Zovoili, A., \& Siatis, V. (2009). Polyphenolic profile and antioxidant activity of five apple cultivars grown under organic and conventional agricultural practices. International Journal of Food Science \& Technology, 44(6), 1167-1175. http://dx.doi.org/10.1111/j.1365-2621.2009.01937.x.

Van der Sluis, A. A., Dekker, M., Skrede, G., \& Jongen, W. M. F. (2002). Activity and concentration of polyphenolic antioxidants in apple juice. 1. Effect of existing production methods. Journal of Agricultural and Food Chemistry, 50(25), 7211-7219. http://dx.doi.org/10.1021/ jf020115h. PMid:12452634.

Yassin, L. S., Alberti, A., Zielinski, A. A. F., Emílio, H. R. O., \& Nogueira, A. (2017). Cytoprotective effect of phenolic extract from brazilian apple peel in insulin-producing cells. Current Nutrition and Food Science, 13, 1-6. http://dx.doi.org/10.2174/157340131366617042 7125753.

Zardo, D. M., Silva, K. M., Guyot, S., \& Nogueira, A. (2013). Phenolic profile and antioxidant capacity of the principal apples produced in Brazil. International Journal of Food Sciences and Nutrition, 64(5), 611-620. http://dx.doi.org/10.3109/09637486.2013.763909 . PMid:23360097.

Zhishen, J., Mengcheng, T., \& Jianming, W. (1999). The determination of flavonoid contents in mulberry and their scavenging effects on superoxide radicals. Food Chemistry, 64(4), 555-559. http://dx.doi. org/10.1016/S0308-8146(98)00102-2.

Zielinski, A. A. F., Alberti, A., Maia Braga, C., Marques da Silva, K., Giovanetti Canteri, M. H., Igarashi Mafra, L., Granato, D., Nogueira, A., \& Wosiacki, G. (2014a). Effect of mash maceration and ripening stage of apples on phenolic compounds and antioxidant power of cloudy juices: A study using chemometrics. Lebensmittel-Wissenschaft + Technologie, 57(1), 223-229. http://dx.doi.org/10.1016/j.lwt.2014.01.029.

Zielinski, A. A. F., Haminiuk, C. W. I., Nunes, C. A., Schnitzler, E., van Ruth, S. M., \& Granato, D. (2014b). Chemical composition, sensory properties, provenance, and bioactivity of fruit juices as assessed by chemometrics: a critical review and guideline. Comprehensive Reviews in Food Science and Food Safety, 13(3), 300-316. http:// dx.doi.org/10.1111/1541-4337.12060. 